\title{
POHREBISKO Z OBDOBIA AVARSKÉHO KAGANÁTU V NITRE-JANÍKOVCIACH ${ }^{1}$
}

\author{
Mário Bielich - Matej Ruttkay - Jozef Zábojník
}

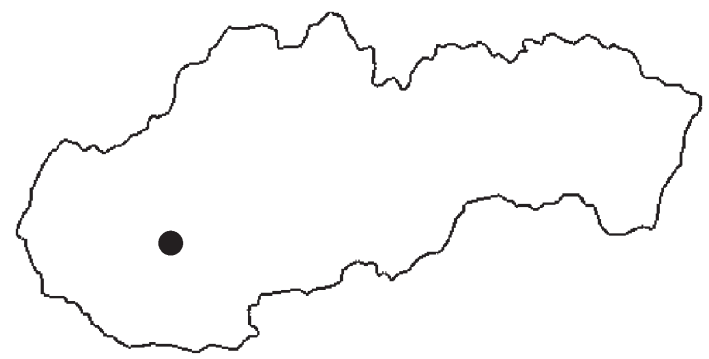

DOI: https://doi.org/10.31577/szausav.2019.66.5

Keywords: Slovakia, Nitra-Janíkovce, Malé Janíkovce, Avar Khaganate, $7^{\text {th }}-8^{\text {th }}$ centuries, graveyard

\section{The cemetery from the period of the Avar Khaganate in Nitra-Janíkovce}

This article informs about the results of rescue archaeological excavations made during the building of R1 expressway by Nitra. On the site at the location Malé Janíkovce, that was excavated in the years 2008 and 2009, settlement of various prehistoric and historical eras was identified. Main focus of the article is the Early Medieval graveyard. Eight skeletal burials were examined. Based on the grave inventories and radiocarbon dating (made by laboratory in Poznan), they can be dated in the period of the heyday of the Avar Kaghanate. Results of the excavations of this graveyard are evaluated in the scope of the Avar settlement of the northern part of the Carpathian Basin.

\section{ÚVOD}

Cielom príspevku je informovat’ o výsledkoch archeologického výskumu realizovanom na pohrebisku z obdobia Avarského kaganátu ležiacom v mestskej časti Nitra-Janíkovce, v katastrálnom území Vel'ké Janíkovce, v polohe Malé Janíkovce (obr. 1). Skúmaný priestor sa nachádza bezprostredne vedla význam-

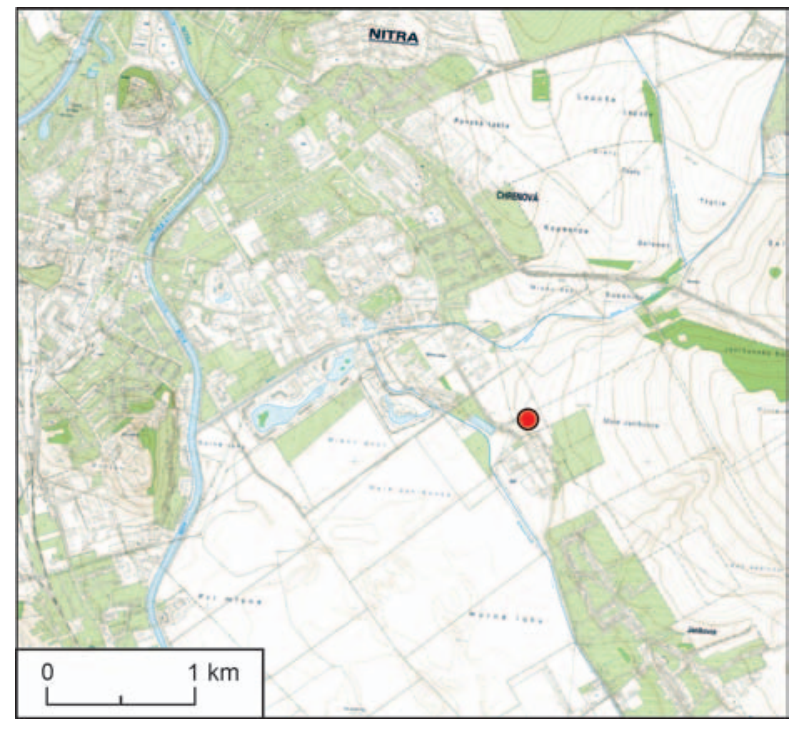

Obr. 1. Nitra-Janíkovce. Pohrebisko z obdobia Avarského kaganátu. Poloha na mape 1:10 000 je fixovaná červeným krúžkom (@ GKU). nej archeologickej lokality Nitra-Mikov dvor. Záchranný archeologický výskum bol podmienený výstavbou rýchlostnej cesty R1 Nitra-západ - Selenec v roku 2008-2010 (Ruttkay a i. 2011, 218; 2013; Ruttkay/Bielich/Daňová 2015). Počas výskumných prác bolo zistené osídlenie z mladšieho praveku, sídlisko zo včasného a vrcholného stredoveku a včasnostredoveké hroby. Predbežne boli informatívnym spôsobom vyhodnotené iba nálezy zo sídliska datovaného do obdobia vrcholného stredoveku (Ruttkay a i. 2016).

\section{DEJINY BÁDANIA}

Najstaršie osídlenie polohy Mikov dvor reprezentujú črepy lengyelskej kultúry pochádzajúce $\mathrm{z}$ kultúrnej vrstvy. Z mladého eneolitu bola $\mathrm{v}$ predmetnom priestore preskúmaná jama skupiny Kosihy-Čaka. Z rozsiahlych výskumov na prelome 70. a 80. rokov 20. stor. pochádza niekol'ko objektov datovaných do mladšej doby laténskej.

1 Práca vznikla v rámci grantových projektov APVV-16-0049, VEGA 2/0075/16 a ako dopadový ukazovatel’ udržatel’nosti projektu ITMS: 26220120059. 


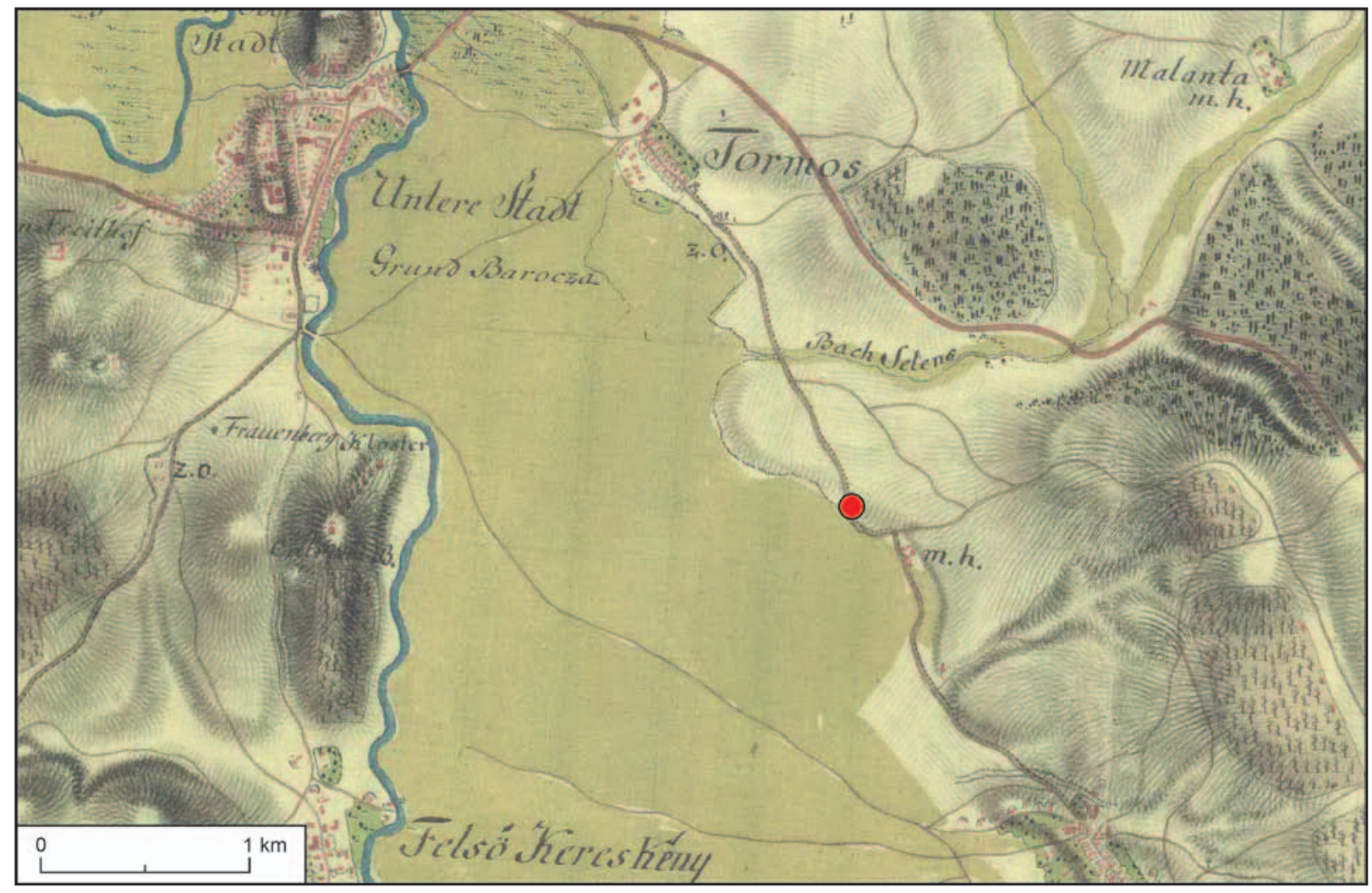

Obr. 2. Nitra-Janíkovce. Poloha pohrebiska na mape 1. vojenského mapovania (@ ARCANUM).

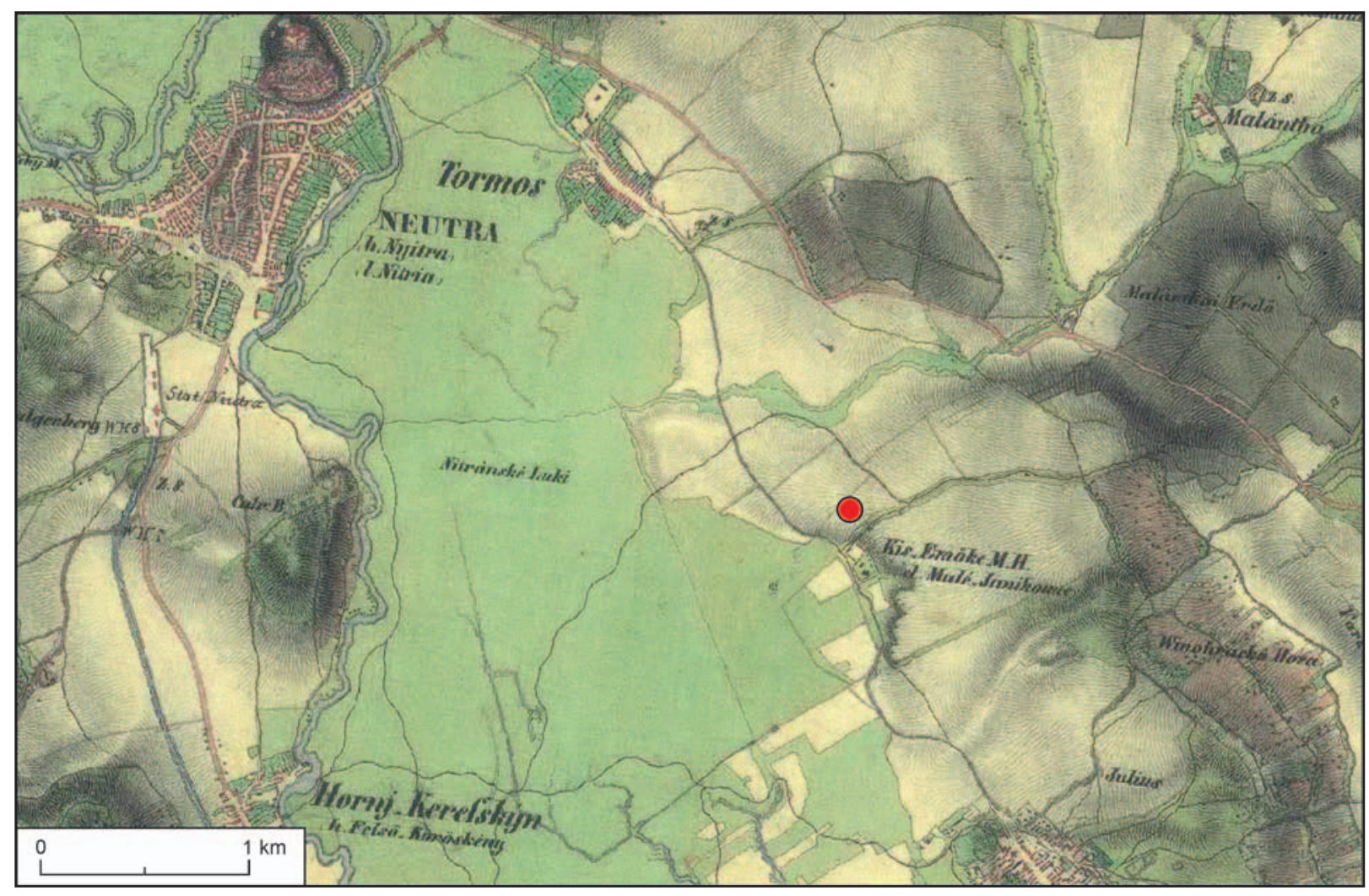

Obr. 3. Nitra-Janíkovce. Poloha pohrebiska na mape 2. vojenského mapovania (@ ARCANUM). 


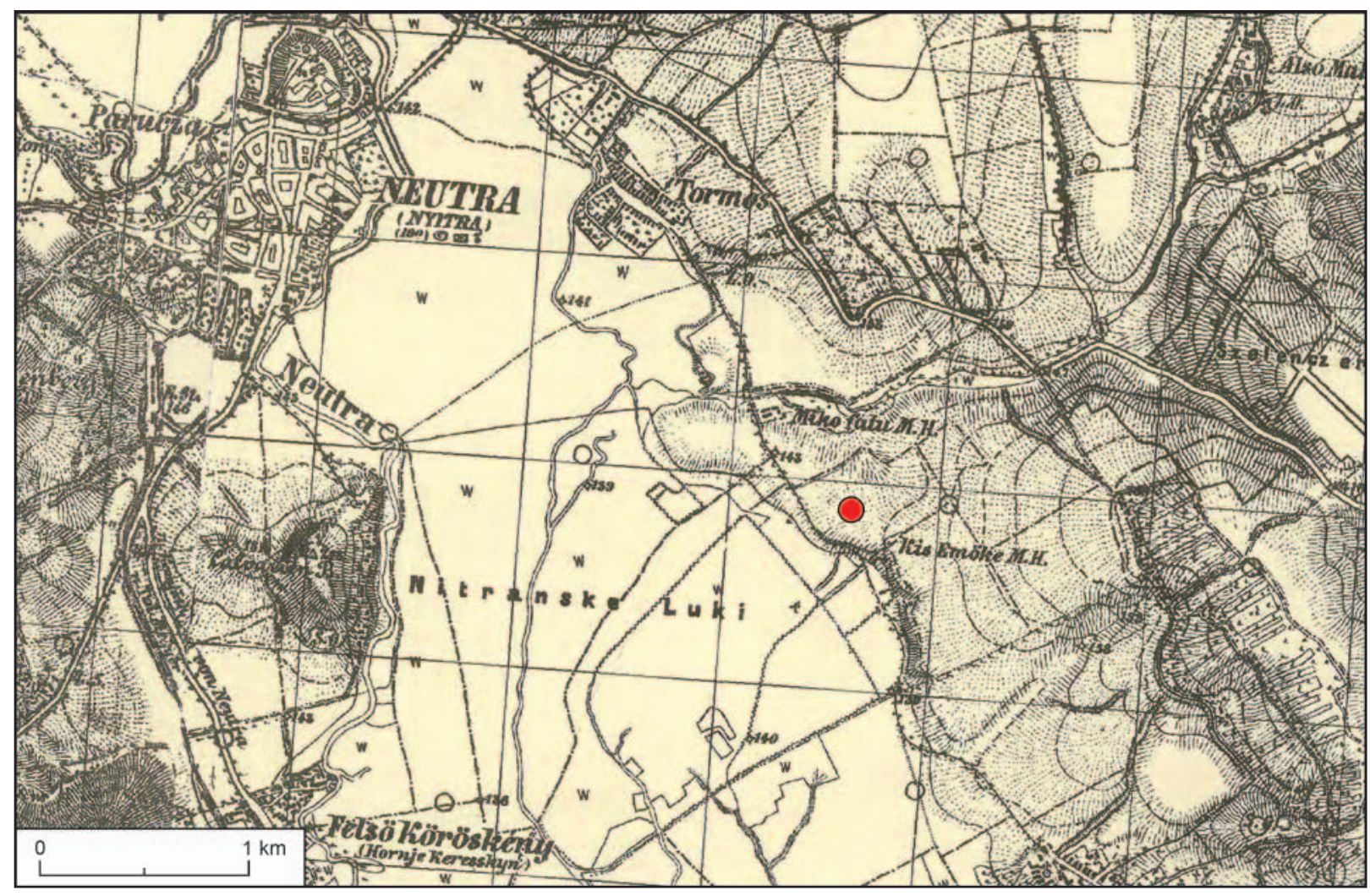

Obr. 4. Nitra-Janíkovce. Poloha pohrebiska na mape 3. vojenského mapovania (@ ARCANUM).

Väčšina objektov však patrí do doby rímskej, pričom do sklonku tohto časového úseku bol datovaný aj jeden kostrový hrob (Pieta 1993, 81, obr. 4). ${ }^{2}$ Bohaté osídlenie možno časovo zaradit do včasného stredoveku. Slovanská osada spolu s pohrebiskom bola pravdepodobne súčastou hospodárskeho zázemia centrálnych hradísk z územia dnešnej Nitry (Chroporský/Fusek 1985b, 102). V blízkosti skúmanej plochy, najmä severne od nej, v širšom priestore Mikovho dvora, sa uskutočnili v minulosti viaceré rozsahom menšie i väčšie archeologické výskumy. Počas nich sa zistili objekty aj hroby zo stredoveku (Hanuliak 1989, 218-220; Chropovský/Fusek 1985a; 1985b; Ruttkay 2015, 54-71). V roku 1958 odkryla M. Rejholcová ${ }^{3}$ tri kostrové hroby z 10.-11. stor. (Hrmová 1956). Ich inventár tvorili hrncovité nádoby, nože, brúsik, kresadlo, kresacie kamienky a esovitá záušnica (Hanuliak 1989, 218). J. Pavúk (1967) preskúmal zemnicu s kamennou pieckou v rohu a hlinenú kupolovú pec z 9.-10. stor., vo výplni ktorej sa našli keramické fragmenty. Na južnom okraji terasovitej vyvýšeniny, nad potokom Selenec a Janíkovským potokom, sa pod vedením B. Chropovského preskúmali v roku 1972 objekty s kamennými pieckami v rohoch (Kováčová 1972). V ich výplni boli zlomky keramiky a zvieracie kosti (Hanuliak 1989, 219). Na severnej strane vyvýšeniny a území po sútok potokov sa uskutočnili rozsiahlejšie výskumy v rokoch 1977-1982 a v roku 1984. Bola odkrytá čast̉ včasnostredovekej osady zo 6.-7. stor. (Fusek 1991), sídlisko z 9.-10. stor. a sídliskové objekty z 12.-13. stor. Včasnostredoveké osídlenie reprezentujú zahĺbené obytné objekty s ohniskami a kamennými pieckami v rohoch, resp. zásobné a odpadové jamy. V ich výplni a v blízkom okolí boli nájdené predmety na prípravu jedla (nádoby, črepy, pekáč, nože), polnohospodárske náradie (kosáky, motyka, otka), predmety dennej potreby (prasleny, pinzeta, brúsiky, šidlá, korčule), zbrane (hroty šípov), platidlo (sekerovitá hrivna) a iné predmety (koráliky, nákončia opaska, ostrohy). Sídlisko z obdobia vrcholného stredoveku (12.-13. stor.) pozostávalo zo zahĺbených objektov s ohniskami a kupolovitými hlinenými pecami v rohoch. Vo výplni objektov sa našli početné fragmenty keramiky, železné predmety (nože, podkovy, ostrohy, klince, skoby, sekera, okutie rýla, obojručný nôž, ihla a klúče) či kamenné brúsiky a kostené korčule (Hanuliak 1989, 219). Do vel'komoravského obdobia možno zaradit 54 kostrových hrobov (Chropovskýl

2 Zdrojom väčšiny prezentovaných údajov sú predovšetkým nálezové správy uložené v archíve Archeologického ústavu SAV v Nitre (Chropovský 1978; Chropovský/Fusek 1985a; Kováčová 1972).

3 Za slobodna M. Hrmová. 
Fusek 1985a; 1985b). Pochovaní boli uložení prevažne vo vystretej polohe na chrbte, ale aj v skrčenej pozícii. Inventár hrobov tvorili keramické hrncovité nádoby, nože, prasleny, kresadlo, kresacie kamienky, sekera, ostrohy, ihelník, krúžkové náušnice s hrozienkom a meandrovite stočenou slučkou, náušnice so stlpikovým i dutým záveskom, prsteň, koráliky a gombíky (Hanuliak 1989, 219). Posledný archeologický výskum v polohe Mikov dvor sa uskutočnil v roku 2017 a realizovala ho súkromná spoločnost' PAMARCH. Počas neho sa zistilo osídlenie z obdobia neolitu (Žaár 2017). Poloha Mikov dvor priamo súvisí s polohou Malé Janíkovce, pričom obe sú kontinuálne osídlené od najstarších čias až do obdobia vrcholného stredoveku.

Plocha archeologickej lokality, na ktorej boli odkryté aj hroby z obdobia Avarského kaganátu bola intenzívne využívaná na polnohospodárske účely. Nachádza sa na terasovitej vyvýšenine pozvolne prechádzajúcej v mierne zvlnený chrbát, ktorý na východe klesá do údolia potoka Selenec. Na mapách vojenských mapovaní (obr. 2-4) možno postrehnút nevýraznú vyvýšeninu, ktorá bola využívaná na pochovávanie. Je to jav bežný nielen v období Avarského kaganátu, kedy sú nekropoly situované na vyvýšenom mieste. Výskum začal v septembri 2008, kedy boli v zistovacích sondách nájdené prvé narušené archeologické objekty. Od augusta 2009 sa uskutočňoval plošný archeologický výskum. Na jeho prvej fáze (začistenie plochy) participovalo Ponitrianske múzeum v Nitre (J. Ruttkayová). Následne výskum viedol Archeologický ústav SAV v Nitre (M. Ruttkay, M. Bielich). V záverečnej etape terénnych prác (január 2010) bolo v severovýchodnej časti skúmanej plochy odkrytých osem kostrových hrobov. Okrem južného okraja sa zachytili všetky hranice tejto malej nekropoly.

\section{KATALÓG HROBOV}

Hrob 1 (tab. I: 1)

Dospelý jedinec.

Hrobová jama: v tvare obdížnika s výrazne zaoblenými rohmi, dí. 260 cm, š. 120 cm, hí. 70 cm (od úrovne zistenia), šikmé steny, rovné dno.

Hrobová konštrukcia: azda rámová konštrukcia, cca $10 \mathrm{~cm}$ nad dnom zúženie v tvare obdížnika.

Poloha pochovaného: kostra natlačená do zúženého priestoru vo vystretej polohe na chrbte s hornými končatinami pozdíž tela. Orientácia: SSZ - JJV $\left(347^{\circ}\right)$.

Nálezy a prílohy: pri kolene lavej dolnej končatiny nádoba (1).

Pozn.: v prírastkovom katalógu pohrebiska (p. č. 789) sa uvádza, že v hrobe sa našla v priestore panvových kostí železná pracka (počas konzervačných prác sa rozpadla).

1. Zdobená obtáčaná hrncovitá nádoba so šikmo zrezaným okrajom, v. $167 \mathrm{~mm}$, max. priemer 137 mm, priemer okraja $123 \mathrm{~mm}$, priemer dna $76 \mathrm{~mm}$ (tab. I: 1: 1).

Hrob 2 (tab. I: 2)

Dieta.

Hrobová jama: nebola odkrytá kompletne. Mala tvar obdížnika so zaoblenými rohmi a Z stranou, dí. odkrytej časti 140 cm, š. $100 \mathrm{~cm}$, hí. $20 \mathrm{~cm}$ (od úrovne zistenia), nevýrazne šikmé stena, rovné dno.

Poloha pochovaného: výrazne porušený hrob. Kosti ludského jedinca porozhadzované po celej hrobovej jame.

Orientácia: SZ - JV $\left(317^{\circ}\right)$, orientácia osi hrobovej jamy.

Nálezy a prílohy: v J polovici hrobovej jamy nádoba (1), poloha zvieracích kostí (2) neurčená.

Pozn.: čast’ hrobovej jamy v priestore pod kontrolným blokom porušená mladším sídliskovým objektom, preto sa nedá určit pôvodná dí. hrobovej jamy.

1. Hrncovitá, obtáčaná a zdobená nádoba s nevýrazne konkávnym dnom, v. $145 \mathrm{~mm}$, max. priemer $118 \mathrm{~mm}$, priemer okraja $100 \mathrm{~mm}$, priemer dna $55 \mathrm{~mm}$ (tab. I: 2: 1).

2. Zvieracie kosti.

Hrob 3 (tab. II: 3)

Diet’a.

Hrobová jama: v tvare obdížnika so zaoblenými rohmi a V stranou. Pred kresbovou dokumentáciou nebola odkrytá kompletne, dí. odkrytej časti $80 \mathrm{~cm}$, š. $75 \mathrm{~cm}$, hí. $50 \mathrm{~cm}$ (od úrovne zistenia), nepatrne šikmé steny, rovné dno.

Poloha pochovaného: výrazne porušený hrob, zachovala sa iba jedna dlhá kost́.

Orientácia: SSZ - JJV $\left(346^{\circ}\right)$, orientácia osi hrobovej jamy.

Nálezy a prílohy: v S časti hrobovej jamy nádoba (1).

Pozn.: po odstránení kontrolného bloku sa zistila celková dí. hrobovej jamy s hodnotou $112 \mathrm{~cm}$.

1. Hrncovitá, obtáčaná a zdobená nádoba s výzdobou aj na okraji, v. $119 \mathrm{~mm}$, max. priemer $103 \mathrm{~mm}$, priemer okraja $90 \mathrm{~mm}$, priemer dna $56 \mathrm{~mm}$ (tab. II: 3: 1).

Hrob 4 (tab. II: 4)

Hrobová jama: v tvare obdížnika so zaoblenými rohmi, dí. 100 cm, š. 50 cm, hí. 15 cm (od úrovne zistenia), nevýrazne šikmé steny, rovné dno.

Poloha pochovaného: v hrobe sa nenašli žiadne pozostatky skeletu. 
Orientácia: SSZ - JJV $\left(333^{\circ}\right)$, orientácia osi hrobovej jamy.

Nálezy a prílohy: bez príloh.

Pozn.: vzhl'adom na malé rozmery hrobovej jamy nemožno vylúčit, že v hrobe bolo pochované malé diet’a, z kostry ktorého sa nič nezachovalo.

Hrob 5 (tab. II: 5)

Dieta.

Hrobová jama: v tvare obdížnika, dí. 185 cm, š. 120 cm, hí. 120 cm (od úrovne zistenia), šikmé steny, rovné dno.

Hrobová konštrukcia: štvorkolová konštrukcia s kolmi v rohoch hrobovej jamy v kombinácii s rámovým obložením.

Poloha pochovaného: zle zachovaná kostra pôvodne azda uložená vo vystretej polohe na chrbte s hornými končatinami pozdíž tela.

Orientácia: JJV - SSZ $\left(157^{\circ}\right)$.

Nálezy a prílohy: konča dolných končatín nádoba (1), z vonkajšej strany obloženia na viacerých miestach zvieracie kosti (2), v zásype vinutie spony (3).

Pozn.: v prírastkovom katalógu pohrebiska sa pod číslom 814 spomína železný hrot (nebol k dispozícii).

1. Obtáčaná, bohato zdobená hrncovitá nádoba so značkou v tvare „kuracej nohy“ na dne, v. 144 mm, max. priemer $120 \mathrm{~mm}$, priemer okraja $95 \mathrm{~mm}$, priemer dna $78 \mathrm{~mm}$ (tab. II: 5: 1).

2. Zvieracie kosti.

3. Bronzové vinutie spony (tab. II: $5: 2$ ).

Hrob 6 (tab. III)

Dospelý, zrejme muž.

Hrobová jama: v tvare obdížnika, dí. 220 cm, š. 120 cm, hí. 110 cm (od úrovne zistenia), zvislé steny, rovné dno.

Hrobová konštrukcia: obloženie v tvare obdližnika zistené cca $20 \mathrm{~cm}$ nad dnom. Zúženie má rozm. 190 x $45 \mathrm{~cm}$.

Poloha pochovaného: vo vystretej polohe na chrbte s hornými končatinami pozdíž tela.

Orientácia: SZ - JV $\left(308^{\circ}\right)$.

Nálezy a prílohy: na lavej panvovej kosti a stranou od nej súprava opaskových kovaní (1), pri pravej panvovej kosti a stehnovej kosti väčší nôž (2), pozdĺž lavej stehnovej kosti menší nôž (3), z vonkajšej strany l'avého predkolenia nádoba (4).

1. Súprava opaskových kovaní: liate bronzové nákončie opaska obojstranne zdobené úponkovým ornamentom. Jeho upínacia čast’ v tvare tul'ajky je s nákončím spojená šarnierom, dí. 62 mm (tab. III: 1/1); nevýrazne lichobežníková liata bronzová pracka s prečnievajúcimi ramenami. Na tylovej časti je fragment objímky naznačujúci pripojenie tylovej doštičky, rozm. 30-32 x 33 mm (tab. III: 1/2); dve celé, jedno neúplne a dva fragmenty tepaných bronzových kovaní kvadratického tvaru s výzdobou v podobe rozety, rozm. celých kusov 20 x 20 mm (tab. III: 6: 1/3); jedno neúplne a dva fragmenty tepaných bronzových kovaní zdobených krúžkami oblemovanými pseudoperlovcom (tab. III: 6: 1/4); jednoduchá plechová prevliečka s vyhnutými koncami má vybíjanú výzdobu, dí. $25 \mathrm{~mm}$, š. $11 \mathrm{~mm}$ (tab. III: 1/5).

2. Väčší železný, tzv. bojový nôž s nevýrazne jednostranne odsadeným tŕňom a zvyškami drevenej pošvy na čepeli, celková dí. 245 mm, dí. čepele 185 mm (tab. III: 2).

3. Menší železný nôž so zaobleným chrbtom a zvyškami drevenej pošvy na čepeli, dí. 155 mm (tab. III: 3).

4. Obtáčaná a zdobená hrncovitá nádoba, v. $147 \mathrm{~mm}$, max. priemer $130 \mathrm{~mm}$, priemer okraja $113 \mathrm{~mm}$, priemer dna $80 \mathrm{~mm}$ (tab. III: 4).

Hrob 7 (tab. IV: 7)

Diet’a.

Hrobová jama: v tvare obdĺžnika, so zaoblenými rohmi dí. 150 cm, š. 60 cm, hí. $10 \mathrm{~cm}$ (od úrovne zistenia), zvislé steny, rovné dno. Poloha pochovaného: vo vystretej polohe na chrbte s hornými končatinami pozdíž tela. Horné končatiny v laktoch pokrčené. Orientácia: S - J $\left(351^{\circ}\right)$.

Nálezy a prílohy: stranou od pravého predkolenia zvieracie kosti (1).

1. Zvieracie kosti.

Hrob 8 (tab. V)

Dospelý, pravdepodobne muž.

Hrobová jama: v tvare obdížnika, dí. 220 cm, š. 70 cm, hí. cca 30 cm (od úrovne zistenia), zvislé steny, rovné dno.

Poloha pochovaného: vo vystretej polohe na chrbte s hornými končatinami pozdíž tela.

Orientácia: S - J $\left(354^{\circ}\right)$.

Nálezy a prílohy: na lavej panvovej kosti pracka (1), druhá pracka (2) na pravej panvovej kosti, na kostiach pravého predlaktia krúžok (3) a nôž (4), druhý nôž na lavej stehnovej kosti (5), povyše pravej panvovej kosti hrot (6), poloha ociel'ky (7), kresacieho kamienka (8) a fragmentu (8) neudaná.

1. Nevýrazne lichobežníková železná pracka. Dí. 46 mm vrátane tŕňa, š. 30-34 mm (tab. V: 1).

2. Neúplná železná pracka s výrazne dovnútra prehnutými ramenami, dí. torza $38 \mathrm{~mm}$ (tab. V: 2).

3. Uzatvorený železný krúžok vyhotovený zo sploštenej tyčinky, priemer $44 \mathrm{~mm}$ (tab. V: 3).

4. Fragment čepele železného noža, dí. $71 \mathrm{~mm}$ (tab. V: 4).

5. Železný nôž s jednostranne odsadeným tŕňom, dí. $118 \mathrm{~mm}$ (tab. V: 5).

6. Železný hrot, azda šidlo, dí. $85 \mathrm{~mm}$ (tab. V: 6).

7. Fragment ociel'ky lýrovitého tvaru, dí. $32 \mathrm{~mm}$ (tab. V: 7).

8. Malý plochý kresací kamienok vyhotovený z limnosilicitu belavej farby, dí. 22 mm (tab. V: 8).

9. Drobný železný fragment z predmetu neznámeho účelu, dí. $31 \mathrm{~mm}$ (tab. V: 9). 


\section{POHREBNÝ RÍTUS}

Z katalógu vyplýva, že preskúmaná bola malá skupina ôsmich kostrových hrobov (obr. 5). $\mathrm{Z}$ nich bolo pät neporušených, $\mathrm{v}$ dvoch sa zistili výrazné stopy sekundárnych zásahov ${ }^{4} \mathrm{a} v$ hrobe 4 sa nezachovali žiadne pozostatky ludského skeletu. Z hladiska veku a pohlavia pochovaných v skupine prevládajú detskí jedinci (tri hroby), v dvoch hroboch boli pochované dospelé indivíduá, v hrobe 6 a 8 bol uložený pravdepodobne muž. V neporušených hroboch boli ludskí jedinci ukladaní vo vystretej polohe na chrbte s hornými končatinami pozdíž tela. Nevýrazné anomálie sú doložené iba nepatrnými flexiami horných končatín (hrob 7).

Rôznorodé úpravy hrobových jám sledovali predovšetkým vytvorenie dutého priestoru v okolí pochovaného tela. Motiváciou pre takéto počínanie boli $\mathrm{v}$ prvom rade pietne dôvody - zamedzenie aspoň primárneho styku zeminy s telesnými pozostatkami zosnulého. Na pohrebisku v Nitre-Janíkovciach boli pozorované pozostatky hrobových konštrukcií v troch prípadoch. V hroboch 1 a 6 to bola zrejme rámová konštrukcia, po ktorej sa nad dnom zachovalo zúženie. V prípade hrobu 5 ide o kombináciu rámovej a kolovej konštrukcie. V zúženom priestore nad dnom bola uložená kostra dietała. Vo všetkých štyroch rohoch sa nachádzali koly. Štvorkolové konštrukcie nie sú ničím neobvyklým na pohrebiskách z obdobia Avarského kaganátu. Zvyčajne sú však situované v dlhších stenách.

Sekundárne zásahy boli pozorované v dvoch prípadoch. Kosti ludského jedinca (dietata) v hrobe 2 boli porozhadzované po celej hrobovej jame. Sekundárnym zásahom bol porušený aj hrob 3. Zo skeletu detského jedinca sa zachovala iba jedna dlhá koste.

Orientácia hrobov, resp. osí hrobových jám osciluje v rozpätí SZ - JV až S - J $\left(308^{\circ}-354^{\circ}\right)$. Jedinou výnimkou je hrob 5. Porušená kostra bola pôvodne uložená pravdepodobne vo vystretej polohe v smere J - S $\left(157^{\circ}\right)$.

Z katalógu vyplýva, že dva hroby boli orientované v smere SZ - JV, iné dva hroby v smere SSZ - JJV, dva hroby v smere $S$ - J (hroby 7 a 8) a jeden hrob mal orientáciu JJV - SSZ. Prekvapuje predovšetkým orientácia v smere S - J, resp. JJV - SSZ (hrob 5). Meridionálny spôsob orientovania hrobov je v období Avarského kaganátu ojedinelý. Viac menej výnimočnú pozíciu nielen na Slovensku, ale aj v rámci celého územia Avarského kaganátu zaujíma pohrebisko v Kechneci (bývalá Hraničná pri Hornáde), kde absolútne dominovala (až 123 prípadov) orientácia v smere J - S (Pástor 1971, 89). V 12 prípadoch boli ludskí jedinci uložení v smere $S$ - J. Aj ked' orientácia vo výrazne meridionálnom smere sa z času načas vyskytuje na viacerých pohrebiskách z obdobia Avarského kaganátu, ide väčšinou o ojedinelé prípady. Pohrebisko v Kechneci možno z tohto zorného uhla považovat za unikát. Či sa dá takýto jav interpretovat’ v zmysle periodického presunu magnetického pólu vo vztahu k zemepisnému a z neho vyplývajúcej zmeny prevládajúcich smerov vetra (Tomka 1986, 165), zostáva vo sfére špekulácií.

Kvôli spresneniu údajov sme orientáciu okrem tradičného udania svetových strán určovali aj meraním uhlov. Zvyčajne sa používa spôsob merania uhla od severu v smere hodinových ručičiek.

\section{Prílohy a spôsob ich deponovania}

Pri výskume pohrebísk z obdobia Avarského kaganátu sa získalo obrovské množstvo predmetov a materiálu súvisiaceho s pohrebmi zosnulých. V predloženom katalógu používame pojem „nálezy

\footnotetext{
4 Zhodou okolností v nich boli pochované deti.
} 
a prílohy“, ktorý vyjadruje sumár všetkých predmetov z hrobu a je dostatočne neutrálny. Čast’ z uvedených predmetov zrejme patrila zomrelému. Kovové súčasti opaska, zbrane, šperky a honosné predmety všeobecne dokladajú predovšetkým sociálny status pochovaného. Je to síce tradične chápaná interpretácia, ale je len tažko predstavitelné, že chudobnému členovi istej pospolitosti mohli uložit do hrobu napríklad kovaniami zdobený opasok. Ten mal istotne cenu nielen z hladiska hodnoty materiálu, ale predovšetkým bol súčastou mužského kroja, symbolizujúcou bohatstvo, moc a spoločenské postavenie svojho nositela (Čilinská 1981, 25). Na pohrebisku z obdobia Avarského kaganátu v Nitre-Janíkovciach sa však súprava opaska vyskytla iba $v$ jednom $z$ hrobov.

Druhou kategóriou predmetov z hrobov sú tie, ktoré pravdepodobne neboli osobným majetkom zomrelého, ale skôr ide o dary pozostalých, resp. predmety súvisiace so samotným aktom pohrebu (napr. nádoba, mäsitá príloha v podobe zvieracích kostí, vajíčko atd’).

Už roky však panuje v členení príloh podla účelu ich použitia značná terminologická zmätenosṫ. Archeologická obec nebola doteraz schopná zjednotit sa na používaní jednoznačného pojmoslovia. Také termíny ako milodar, inventár mŕtveho, hrobový inventár a pod. nevyjadrujú jednoznačne účel, ktorý bol určitému predmetu daný (Hanuliak 2004, 121 s literatúrou).

Deponovanie príloh je dôležité z hladiska ich umiestnenia v tzv. „funkčnej polohe“. Kovania opaska sa zvyčajne nachádzajú v priestore panvových kostí, náušnice v okolí lebky, náhrdelník okolo krku, konský postroj na skelete koňa a pod. Všetky výnimky z uvedeného úzu mali zrejme svoje príčiny, ktoré sa za istých okolností dajú vysvetlit. Vzhl'adom na skutočnost', že na pohrebisku v Nitre-Janíkovciach bola preskúmaná iba malá skupina hrobov, nemožno vyvodzovat žiadne d’alekosiahle závery týkajúce sa polohy predmetov $\mathrm{v}$ hroboch. Výnimku predstavuje hrob 6, v ktorom bola súprava opaskových kovaní deponovaná na l’avej panvovej kosti, resp. v jej susedstve. Vzniká dojem, že opasok nebol v tzv. funkčnej polohe, ale uložený $\mathrm{k}$ boku pochovaného.

\section{Materiálna kultúra}

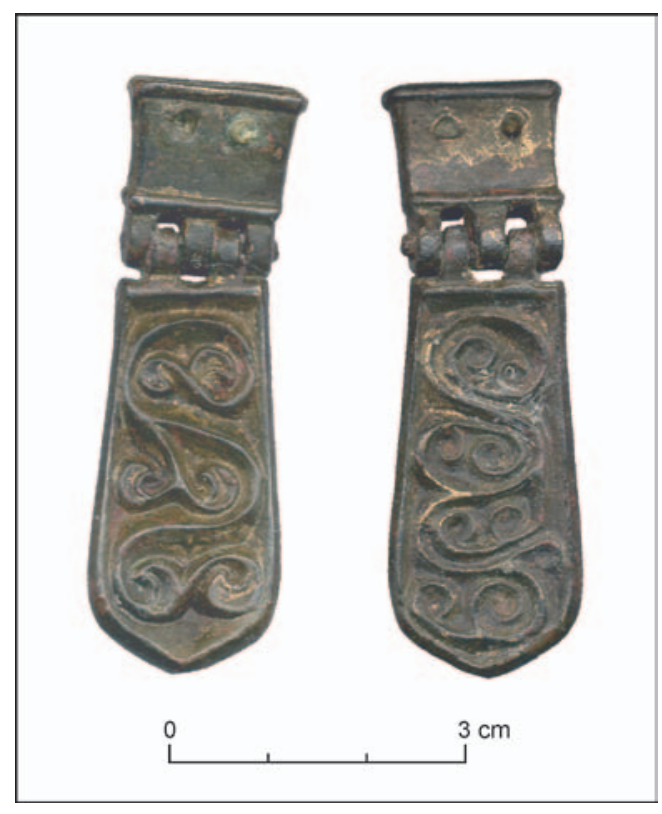

Obr. 6. Nitra-Janíkovce. Nákončie z hrobu 6.

Najdôležitejším celkom na pohrebisku v Nitre-Janíkovciach je hrob 6. Obsahoval súpravu opaskových kovaní, dva nože a štyri kresacie kamienky. Garnitúra pozostávala z liateho nákončia (obr. 6), plechových kvadratických kovaní, štvoruholníkovej pracky s presahujúcimi stranami a plechovej prevliečky. Jej súčastou boli zrejme aj plechové kovania zdobené krúžkami lemovanými perlovcovou výzdobou. Keďže sa zachovali iba vo fragmentoch, je viac-menej nemožné rozpoznat ich pôvodný tvar.

Vel'ké nákončia, ktorých upínacia tylová doštička je spojená $\mathrm{s}$ telom nákončia prostredníctvom šarniera, sú síce v nálezovom materiáli z obdobia Avarského kaganátu pomerne zriedkavé, nepredstavujú však žiaden výnimočný jav. Najčastejšie ide o liate bronzové exempláre, ktorých výzdoba pozostáva zo zoomorfných i rastlinných motívov. Do prvej skupiny patrí napr. nákončie z jazdeckého hrobu 11 na pohrebisku Dévaványa (Kovrig 1975, 126, obr. 4: 11: 23), ktorého strany sú rovnobežné. Konkávne dovnútra prehnuté strany má viacero nákončí zdobených zoomorfnými motívmi. ${ }^{5}$ Velimi bohatú rastlinnú výzdobu nesie nákončie z Mártély (Hampel 1905, tab. 85: 1) a jeho vel'mi presná paralela z hrobu 38 na pohrebisku Gyód (Kiss 1977, 40, tab. VII: 38: 2). Z hladiska nákončia z hrobu 6 na pohrebisku v Nitre-Janíkovciach je významný exemplár z pohrebiska Ordas (Hampel 1905, tab. 80: 2). Jeho lícna strana je zdobená rastlinným motívom, ktorý má viacero analógií na predmetoch z pokladu nájdeného $\mathrm{v}$ dedinke Vrap v Albánsku (Werner 1986, tab. 13), resp. z komplexu pochádzajúceho z lokality Erseke v Grécku (Avar treasure 1981, 13, LOT 168, 15, LOT 169).

\footnotetext{
5 Je ich viacero, preto nepovažujeme za zmysluplné ich vymenúvanie (ich súpis porovnaj Stadler 1986, 117, 118, mapa 6).
} 
Výnimočným je nákončie z hrobu 166 na pohrebisku Tiszafüred-Majoroshalom (Garam 1995, 26, tab. 71: 166: 4). V hrobe bola pochovaná žena, ktorej dali do hrobu dve zlaté náušnice a kotúčovitú bronzovú ozdobu. Súčastou inventára boli aj koráliky v tvare melónového jadra. Nákončie je vyhotovené z pozláteného bronzového plechu a zdobené pletencovou výzdobou. Ostatné exempláre s pohyblivou tylovou doštičkou majú konkávne strany a vo väčšine prípadov zahrotený koniec, čo sú tvarové špecifiká starších fáz neskorého stupňa (Zábojník 1991, 237).

Prednedávnom bola publikovaná špeciálna štúdia zaoberajúca sa nákončiami s tylovou doštičkou spojenou s nákončím prostredníctvom šarniera, ktorej autorom je mad’arský bádatel' G. Szente (2013). Prezentuje ich súpis na území tvoriacom Avarský kaganát, ktorý je doplnený o priestorové vyhodnotenie na mapách. Dáva ich do súvisu s antickými, resp. byzantskými tradíciami Stredomoria. Vyjadruje sa aj k ich chronologickej pozícii v rámci obdobia Avarského kaganátu. Liate exempláre, najmä tie, ktoré majú konkávne strany a zahrotené ukončenia sú zdobené rôznorodými zoomorfnými, predovšetkým však rastlinnými motívmi. Ich datovanie do starších fáz neskorého stupňa je viac ako pravdepodobné.

Viacero nákončí s upevňovacou doštičkou spojenou šarnierom pochádza aj z pohrebiska Zamárdi-Rétiföldek (Bárdos/Garam 2009, tab. 178: 1, 3, 6; 179: 1; 184: 9; 213: 2; 2014, tab. 224: 2144: 2; 241: 2302: 12). Zvyčajne sú zdobené v zmysle tzv. zvieracie štýlu $\mathrm{II}^{6}$ a vyhotovené zo zlata, striebra, resp. pozláteného striebra. Zo šiestich hrobov obsahujúcich nákončia so šarnierom až štyri patrili ženám. Nie je to nič prekvapujúce, kedže takéto kovania tvorili jednotlivé zložky pásových závesov.7 Tie boli súčastou kroja popredných germánskych žien strednej, západnej, severnej i východnej Európy a datujú sa v avarskom prostredí do včasného stupňa obdobia (Vida 2015, 159). Dokladajú to početné nálezy na pohrebiskách, na ktorých zrejme pochovávali svojich mŕtvych aj germánske skupiny začlenené do spoločnosti Avarského kaganátu, napr. Zamárdi, Budakalász, Csákberény a dalšie (Vida 1996, 108-118). Hroby 805 a 2302 na pohrebisku v Zamárdi, v ktorých boli pochovaní muži, obsahovali kompletné garnitúry. Tie však možno jednoznačne datovat do neskorého stupňa.

Z hladiska datovania hrobu 6 na pohrebisku v Nitre-Janíkovciach majú mimoriadny význam plechové tepané kvadratické kovania (obr. 7). Sú blízke typu 179 v seriácii súprav opaskových kovaní zo severnej časti Karpatskej kotliny a charakteristické pre mladšiu fázu stredného stupňa (Zábojník 1991, 235). Súpravy pozostávajúce z kvadratických tepaných plechových kovaní, doplnené liatym nákončím, nie sú výnimočné v prostredí pohrebísk z obdobia Avarského kaganátu. ${ }^{8}$ Súčastou súpravy opaskových kovaní z hrobu 6 na pohrebisku v Nitre-Janíkovciach bola aj jednoduchá plechová prevliečka s vyhnutými koncami, zdobená vybíjaným ornamentom. Tento typ dekorácie sa objavuje na plechových kovaniach charakteristických pre prvú fázu neskorého stupňa (Zábojník 1991, 236).

Azda jediným predmetom, ktorý možno začlenit do skupiny zbraní je pomerne masívny nôž z hrobu 6. Jeho čepel’ je dlhá

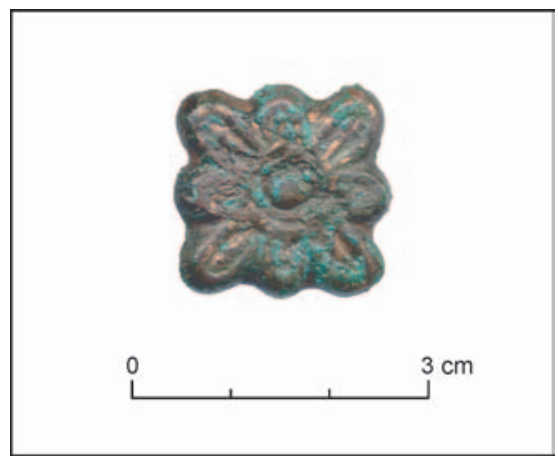

Obr. 7. Nitra-Janíkovce. Kvadratické plechové kovanie z hrobu 6. $185 \mathrm{~cm}$, čo umožňuje jeho priradenie k tzv. bojovým nožom.

Túto domnienku umocňuje aj nález druhého noža z tohto hrobu. V prípade výskytu dvoch nožov v jednom celku sa predpokladá, že jeden z nich slúžil ako zbraň (Zábojník 1995, 252).

Do skupiny predmetov dennej potreby možno zaradit železné pracky, železný krúžok, nože, hrot, ociel'ku a kresacie kamienky. Dve železné pracky, dva železné nože, ociel'ka, železný krúžok, železný hrot a kresací kamienok tvorili inventár hrobu 8. Dva nože obsahoval aj hrob 6. Z nich jeden možno považovat' za tzv. bojový nôž. Súčastami inventára tohto celku boli aj štyri kresacie kamienky. ${ }^{9} \mathrm{~V}$ tomto prípade síce absentovala ociel'ka, ale ako kresadlo mohol slúžit hocijaký železný predmet. V prírastkovom katalógu pohrebiska sa pod číslom 789 uvádza železná pracka nájdená v priestore panvových kostí. Uvedené predmety nemožno využit na precíznejšie datovanie hrobov.

6 V nemecky písanej literatúre sa pre tento druh výzdoby používa výraz „Zahnschnittornamentik“ (Ament 2005, 597).

7 Nemecky Gürtelgehänge.

8 Dokladá to napr. garnitúra z hrobu 242 na pohrebisku Mödling (údaje o tomto nálezovom celku nám poskytol F. Daim, za čo mu úprimne d’akujeme).

9 Nakreslené boli štyri kusy, v prírastkovom katalógu pohrebiska sa pod číslom 822 spomínajú iba dva kusy. Ked’že hroby sú v superpozícii so starším osídlením, nemožno vylúčit, že kresacie kamienky, resp. úštepy pochádzajú zo starších objektov. 
V piatich hroboch analyzovaného pohrebisk $a^{10}$ sa našli keramické nádoby. Ide o obtáčané a zdobené hrncovité nádoby zdobené pomocou hrebeňa. Na niektorých z nich (nádoby z hrobov 1 a 6 ) sú na vnútorných častiach okrajov pozorované stopy po použití nástrojov na uhladenie. Nádoba z hrobu 3 má výzdobu v podobe dvojitej vlnovky aj na hornej časti okraja. Nádoba z hrobu 5 mala na dne plastickú značku v tvare „kuracej nohy“. Obdobné značky nie sú ničím výnimočným na pohrebiskách z obdobia Avarského kaganátu, čo dokladajú aj viaceré nálezy z územia Slovenska (Točík 1962, 372, obr. 18). Ich výskyt pokračuje aj na keramike datovanej do vel'komoravského obdobia (Kraskovská 1983, 194, tab. I, typ 26). Nie sú neobvyklé ani na susednom teritóriu Čiech a Moravy (Varadzin 2004, 193, typy 379-382). Datovanie keramických nádob, podobne ako v prípade predmetov dennej potreby je len rámcové. Predstavujú keramickú produkciu 8 . storočia.

V zásype hrobu $5 \mathrm{v}$ híbke asi $50-60 \mathrm{~cm}^{11}$ sa našlo bronzové vinutie spony, ktorú možno s vel'kou pravdepodobnostou datovat' do doby rímskej.

Zvieracie kosti pochádzajú z troch hrobov (hroby 2, 5 a 7). V zásypoch hrobov 1 a 5 sa našli zvyšky malakofauny. Kedže hroby sú v superpozícii so starším osídlením, nemožno vylúčit, že sa do zásypov hrobových jám dostali pri ich híbení.

\section{VYHODNOTENIE A DATOVANIE POHREBISKA}

Na základe materiálu z jedného z hrobov ${ }^{12}$ pohrebiska Nitra-Horné Krškany, poloha Bioveta, ${ }_{13}^{13}$ sa predpokladalo, že oblast’ okolo Nitry bola zahrnutá do Avarského kaganátu niekedy v priebehu druhej polovice 8. stor. Súprava opaskových kovaní z hrobu 6 na pohrebisku Nitra-Janíkovce tento postulát výrazne mení. Možno ju pomerne spol’ahlivo datovat do prvej štvrtiny, resp. prvej tretiny 8. stor. V hrobe bol pochovaný mladý muž, preto sa dá predpokladat,, že súpravu vlastnil iba krátko. V tejto súvislosti je potrebné spomenút kostrový hrob z Ivanky pri Nitre, ktorý obsahoval nádobu pomerne archaického vzhladu (Fusek 1994, 229, tab. XXXII: 3). Skoršieho datovania než druhá polovica 8. stor. je zrejme aj železný strmeň nájdený v sídliskovom objekte v Nitre-Chrenovej (Zábojník 2009, 106, tab. 14: A). Taktiež trojkrídelkový hrot šípu nájdený vo výplni objektu 232, ktorý bol datovaný do včasnoslovanského obdobia (Fusek 1991, 296, obr. 6: 4). Na základe prezentovaných údajov predpokladáme, že teritórium okolo mesta Nitra bolo začlenené do politickej štruktúry Avarského kaganátu najneskôr začiatkom 8. stor.

\section{APENDIX}

Prednedávnom boli odbornej verejnosti sprístupnené výsledky analýz organických vzoriek pomocou rádiouhlíkovej metódy $\mathrm{z}$ viacerých lokalít. V laboratóriu v Poznani sa uskutočnila analýza antropologického materiálu z hrobu 6 z pohrebiska v Nitre-Janíkovciach. ${ }^{14}$ Žial', pre precíznejšie časové určenie tohto celku nepriniesla požadovanú presnost’ vzhl’adom na dosť širokú toleranciu absolútneho datovania.

\section{Pod'akovanie}

Je našou milou povinnostou pod'akovat' sa spolupracovníkom, ktorí sa podielali na vzniku tohto príspevku. Za kresby materiálu z hrobov sme vd’ační J. Mészarosovej, Ž. Nagyová je autorkou kresieb keramiky, S. Štefankovej sme zaviazaní za zostavenie tabuliek. Autorom niekol'kých ilustráciú (obr. 1-4) je M. Bartík, skeny bronzových kovaní (obr. 6; 7) vyhotovila E. Čaprdová. Za preklad súhrnu do anglického jazyka chceme pod'akovat' V. Tejbusovej, za jazykovú úpravu jej prekladu vd'ačíme M. Holeščákovi.

\footnotetext{
10 V každom prípade po jednom kuse.

11 Pravdepodobne od úrovne zistenia, pretože hrobová jama mala híbku $120 \mathrm{~cm}$.

12 Hrob 5 (pôvodne označený ako hrob 2/52) obsahoval velmi mladú súpravu opaskových kovaní (Zábojník 2009, 105, tab. 11: 1).

13 Dnes závod Mevak, a. s. V súpise nálezov a nálezísk z obdobia Avarského kaganátu (Zábojník 2009, 104) je lokalita nesprávne uvádzaná pod názvom Nitra-Dolné Krškany.

14 Datovanie $1305 \pm 35,95,4 \%$ probabillity, 656 (95,4 \%) 770 cal AD (Ruttkay a i. 2016, 47).
} 

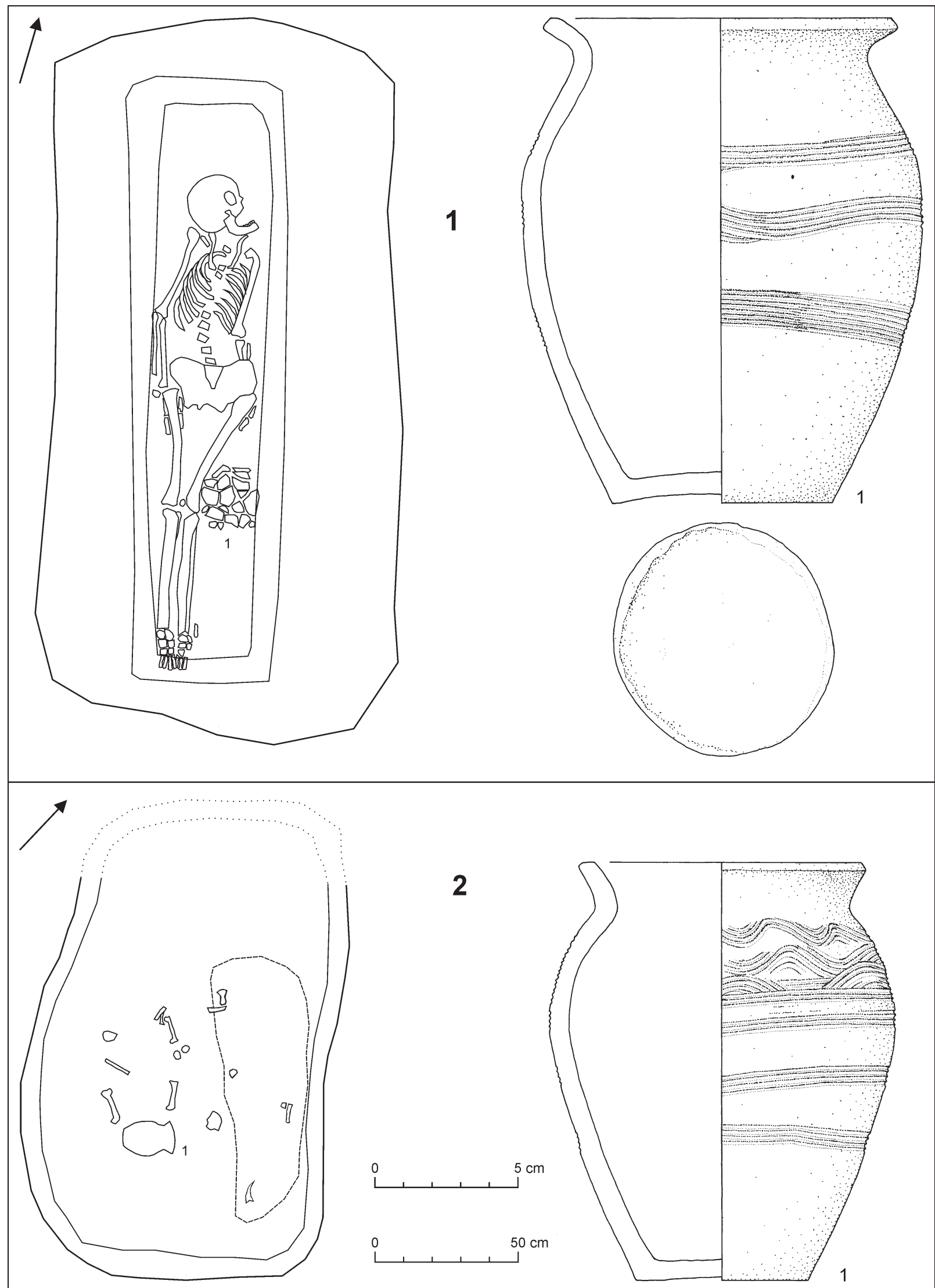

Tab. I. Nitra-Janíkovce. Hroby 1 a 2. 


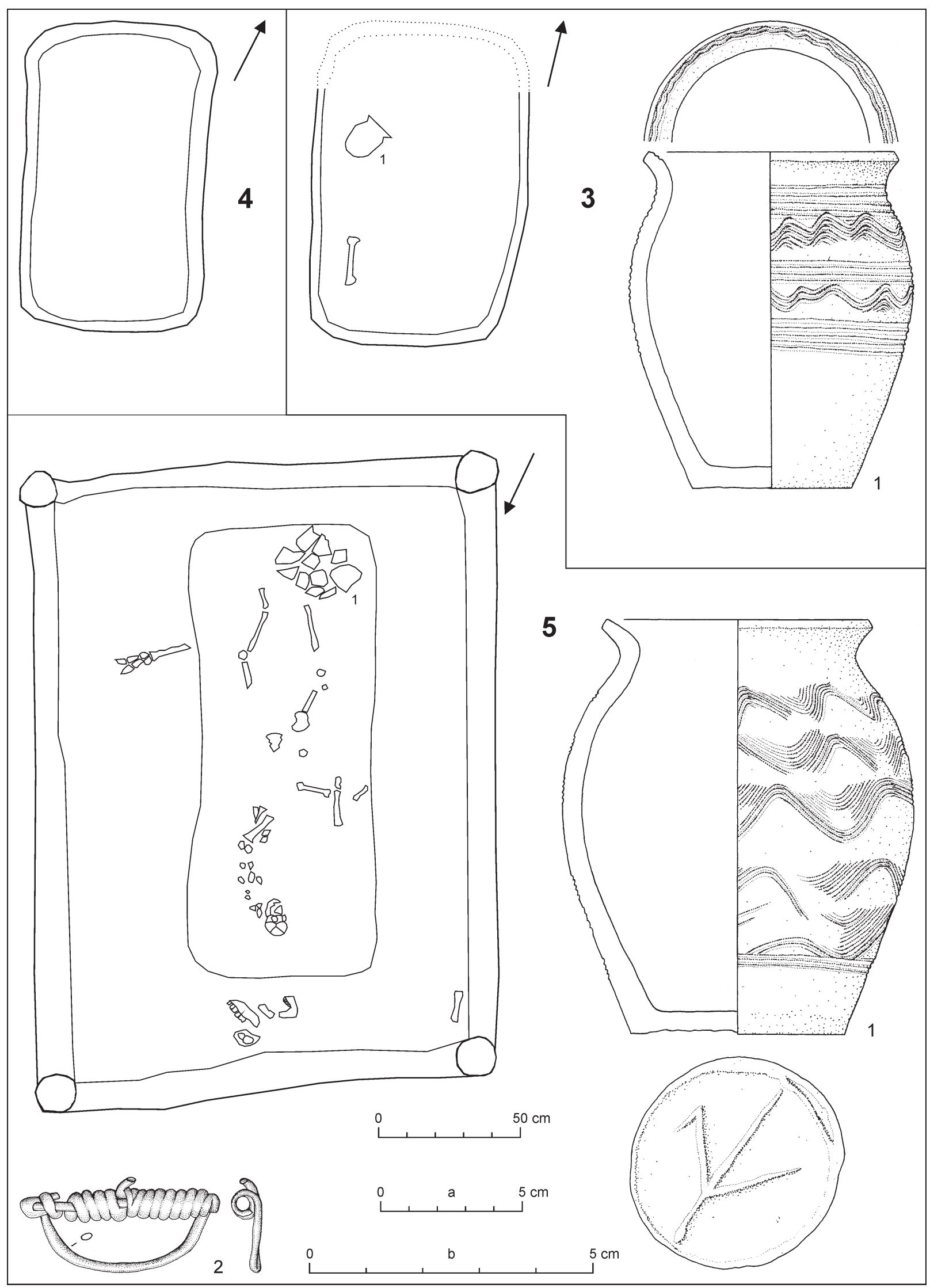

Tab. II. Nitra-Janíkovce. Hroby 3-5. 


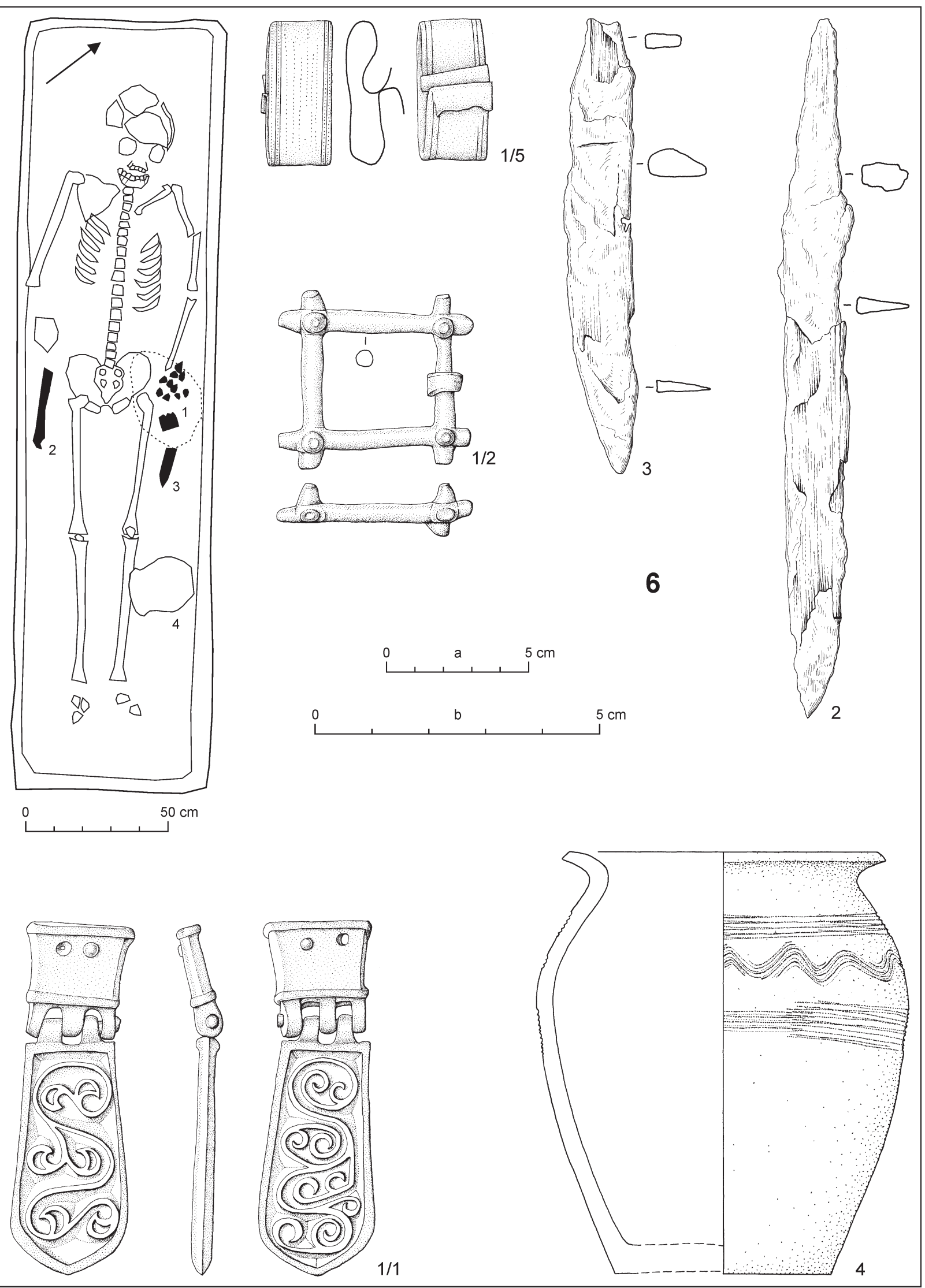

Tab. III. Nitra-Janíkovce. Hrob 6. 


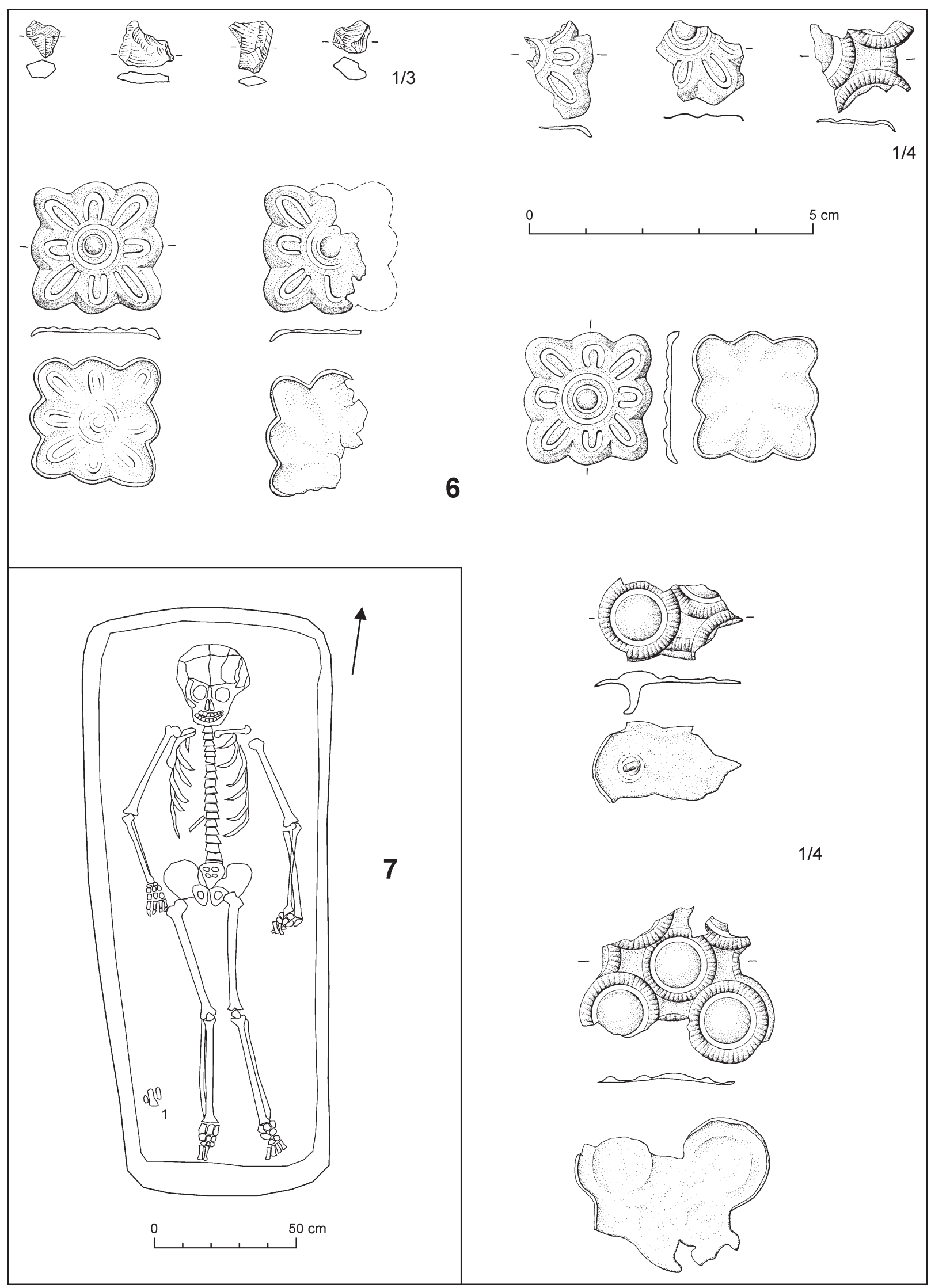

Tab. IV. Nitra-Janíkovce. Hroby 6 a 7 


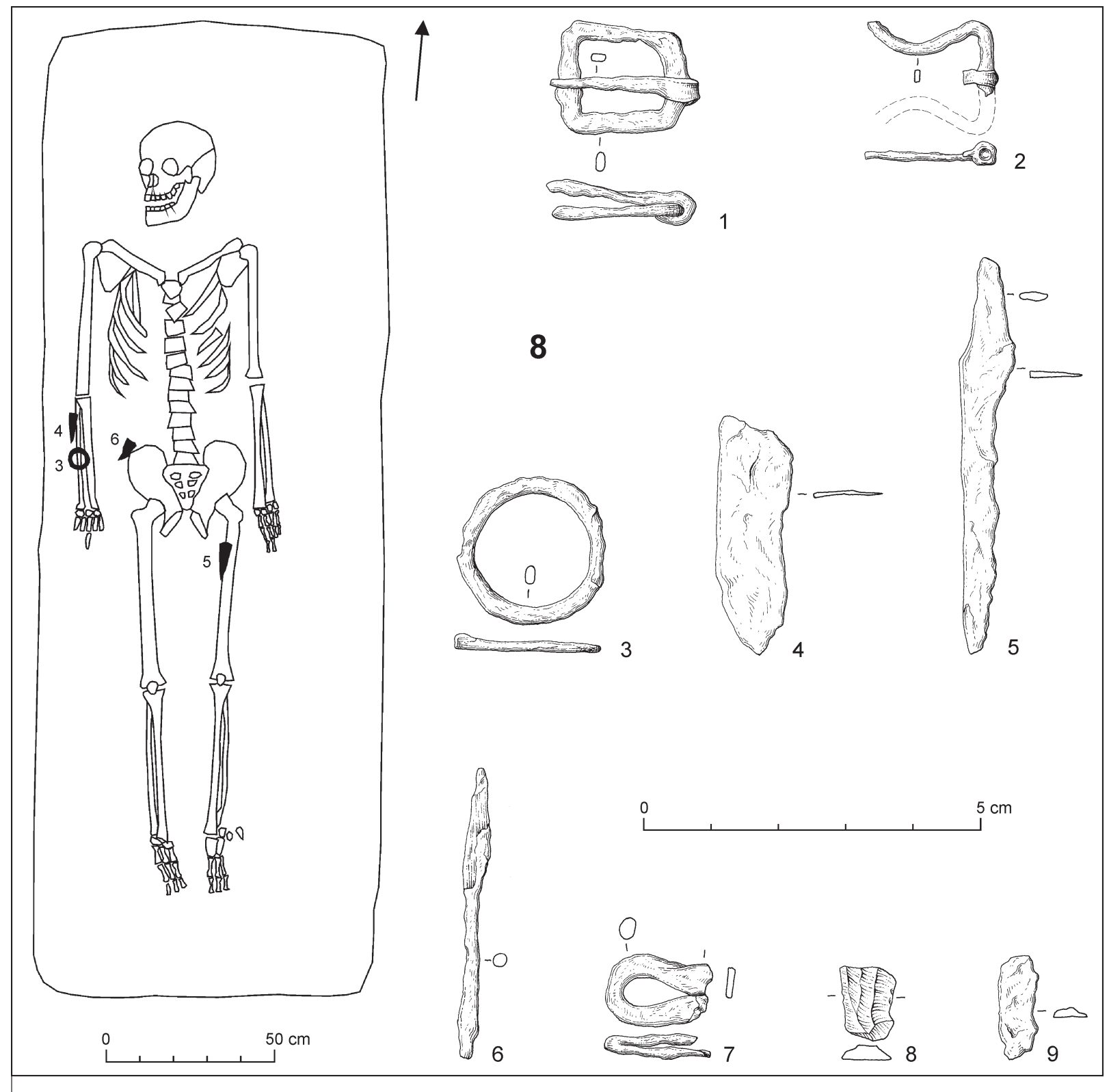

Tab. V. Nitra-Janíkovce. Hrob 8. 


\section{LITERATÚRA A PRAMENE}

Ament 2005

Avar treasure 1981

Bárdos/Garam 2009

Bárdos/Garam 2014

Čilinská 1981

Fusek 1991

Fusek 1994

Garam 1995

Hampel 1905

Hanuliak 1989

Hanuliak 2004

Hrmová 1956

Chroporský 1978

Chropovský/Fusek 1985a

Chropovský/Fusek 1985 b

Kiss 1977

Kováčová 1972

Kovrig 1975

Kraskovská 1983

Pástor 1971

Pavúk 1967

Pieta 1993

Ruttkay 2015

Ruttkay/Bielich/Daňová 2015

Ruttkay a i. 2011

Ruttkay a i. 2013
H. Ament: Awarengebiet. In: H. Beck/D. Geuenich/H. Steuer (Hrsg.): Reallexikon der Germanischen Altertumskunde 30. Berlin - New York 2005, 597, 598. Catalogue of the Avar Treasure, Comprising one hundred and twenty-two gold and silver belt fittings of the Avar period, circa $700 \mathrm{~A}$. D. Together with two Byzantine silver plates bearing Constantinopolitan control stamps of the $7^{\text {th }}$ Century. Sotheby Parke Barnet \& Co. London - Bradford 1981.

E. Bárdos/É. Garam: Das awarenzeitliche Gräberfeld in Zamárdi-Rétiföldek. Monumenta Avarorum Archaeologica 9. Budapest 2009.

E. Bárdos/É. Garam: Das awarenzeitliche Gräberfeld in Zamárdi-Rétiföldek. Monumenta Avarorum Archaeologica 10. Budapest 2014.

Z. Čilinská: Kov v ranoslovanskom umení. Dávnoveké umenie Slovenska. Ars slovaca antiqua 12. Bratislava 1981.

G. Fusek: Včasnoslovanské sídlisko v Nitre na Mikovom Dvore. Slovenská archeológia 39, 1991, 289-330.

G. Fusek: Slovensko vo včasnoslovanskom období. Archaeologica Slovaca Monographiae 3. Nitra 1994.

É. Garam: Das awarenzeitliche Gräberfeld von Tiszafüred. Cemeteries of the Avar Period (567-829) in Hungary 3. Budapest 1995.

J. Hampel: Alterthümer des frühen Mittelalters in Ungarn. I-III. Braunschweig 1905.

M. Hanuliak: Okres Nitra. In: D. Bialeková (zost.): Pramene k dejinám osídlenia Slovenska z konca 5. až z 13. storočia. I. zväzok, 2. čast'. Nitra 1989, 179-235.

M. Hanuliak: Vel'komoravské pohrebiská. Pochovávanie v 9.-10. storočí na území Slovenska. Archaeologica Slovaca Mongraphiae. Studia VIII. Nitra 2004.

M. Hrmová: Nitra-Mikov dvor. Nálezová správa 1560/1958. Archív Archeologického ústavu SAV v Nitre. Nitra 1956.

B. Chropovský: Nitra-Mikov dvor. Nálezová správa 8368/1978. Archív Archeologického ústavu SAV v Nitre. Nitra 1978.

B. Chropovský/G. Fusek: Nitra-Mikov dvor. Nálezová správa 11028/1985. Archív Archeologického ústavu SAV v Nitre. Nitra 1985.

B. Chropovský/G. Fusek: Výskumy v Nitre. AVANS v roku 1984, 1985, 102-106.

A. Kiss: Avar Cemeteries in County Baranya. Cemeteries of the Avar Period (567-829) in Hungary 2. Budapest 1977.

A. Kováčová: Nitra-Mikov dvor. Nálezová správa 5941/1972. Archív Archeologického ústavu SAV v Nitre. Nitra 1972.

I. Kovrig: The Dévaványa Cemetery. In: É. Garam/I. Kovrig/J. Gy. Szabó/ Gy. Török (ed.): Avar Finds in the Hungarian National Museum. Cemeteries of the Avar Period (567-829) in Hungary 1. Budapest 1975, 121-155.

L. Kraskovská: Značky na nádobách z doby vel'komoravskej. Študijné zvesti AU SAV 20, 1983, 193-206.

J. Pástor: Kostrové pohrebisko v Hraničnej pri Hornáde. Východoslovenský pravek 2, 1971, 89-179.

J. Pavúk: Nitra-Mikov dvor. Nálezová správa 2306/1967. Archív Archeologického ústavu SAV v Nitre. Nitra 1967.

K. Pieta: Osídlenie z doby rímskej a st’ahovania národov v Nitre. In: K. Pieta (red.): Nitra. Príspevky k najstarším dejinám mesta. Nitra 1993, 74-90.

M. Ruttkay: V dávnej minulosti. In: P. Keresteš (zost.): Janíkovce. Dejiny Janíkoviec od najstarších čias až po súčasnost'. Nitra 2015, 35-72.

M. Ruttkay/M. Bielich/K. Daňová: Záchranné archeologické výskumy na trase výstavby rýchlostnej cesty R1 v úseku Nitra-západ - Selenec. AVANS v roku 2010, 2015, 208-210.

M. Ruttkay/P. Bednár/M. Bielich/M. Cheben: Archeologický prieskum $\mathrm{v}$ rámci prípravy stavby $\mathrm{R} 1 \mathrm{v}$ úseku Nitra-západ - Selenec. AVANS v roku 2008, 2011, 220-221.

M. Ruttkay/M. Bielich/B. Milová/R. Malček/A. Nemergut/J. Ruttkayová/ B. Zajacová: Záchranné archeologické výskumy na trase výstavby rýchlostnej cesty R1 v úseku Nitra-západ - Selenec. AVANS v roku 2009, 2013, 200-209. 
Ruttkay a i. 2016

Stadler 1986

Szente 2013

Točík 1962

Tomka 1986

Varadzin 2004

Vida 1996

Vida 2015

Werner 1986

Zábojník 1991

Zábojník 1995

Zábojník 2009

Žaár 2017
M. Ruttkay/J. Ruttkayová/M. Bielich/B. Zajacová/A. Nemergut: Sídlisko z 10.-12. storočia v Nitre-Janíkovciach. Archaeologia historica 41/2, 2016, 41-58.

P. Stadler: Ausgewählte awarische Bronzegüsse als Parallelen zu Gürtelbeschägen von Vrap und Erseke. In: J. Werner 1986, 105-118.

G. Szente: Connections between the Mediterranean and the Carpathian Basin in the $8^{\text {th }}$ century AD. On the hinged strap-ends of the Late Avar Period. Acta Archaeologica Carpathica 48, 2013, 195-225.

A. Točík: Keramika so značkami na dne zo slovansko-avarských pohrebísk na juhozápadnom Slovensku. Památky archeologické 53, 1962, 347-380. P. Tomka: Archäologische Studien zur Ethnographie der awarenzeitlichen Völker. Mitteilungen der Anthropologischen Gesellschaft Wien 116, 1986, 155-168.

L. Varadzin: Značky na dnech keramických nádob ve středověku. Studia Mediaevalia Pragensia 5, 2004, 165-199.

T. Vida: Bemerkungen zur awarenzeitlichen Frauentracht. In: D. Bialeková/J. Zábojník (Hrsg.): Ethnische und kulturelle Verhältnisse an den mittleren Donau vom 6. bis zum 11. Jahrhundert. Nitra 1996, 107-124.

T. Vida: Gürtelgehänge der Frauen und ihr Zubehör. In: Gy. László (ed.): Das awarenzeitliche Gräberfeld in Csákberény-Orondpuszta. Monumenta Avarorum Archaeologica 11. Budapest 2015, 159-164.

J. Werner: Der Schatzfund von Vrap in Albanien. Studien zur Archäologie der Awaren 2. Wien 1986.

J. Zábojník: Seriation von Gürtelbeschlaggarnituren aus dem Gebiet der Slowakei und Österreichs (Beitrag zur Chronologie der Zeit des Awarischen Kaganats). In: Z. Čilinská (zost.): K problematike osídlenia stredodunajskej oblasti vo včasnom stredoveku. Nitra 1991, 219-321.

J. Zábojník: Soziale Problematik des nördlichen und nordwestlichen Randgebietes des Awarischen Kaganats. Slovenská archeológia 43, 1995, 205-344.

J. Zábojník: Slovensko a avarský kaganát 2. Studia Archaeologica et Medievalia 9. Bratislava 2009.

O. Žaár: Nitra-Mikov dvor. Nálezová správa 19506/2017. Archív Archeologického ústavu SAV v Nitre. Nitra 2017.

\title{
The cemetery from the period of the Avar Khaganate in Nitra-Janíkovce
}

\author{
Mário Bielich - Matej Ruttkay - Jozef Zábojník
}

Summary

The goal of the article is to inform about the results of the archaeological research carried out at the cemetery from the Avar Khaganate period situated in Nitra-Janíkovce, in the cadastral area of Vel'ké Janíkovce, Malé Janíkovce site (Fig. 1). The studied area is situated in the immediate vicinity of the important archaeological site of NitraMikov dvor. The rescue research was initiated by the construction of R1 expressway from Nitra-západ to Selenec in 2008-2010. During research activities, settlement from the late prehistory was detected, as well as a settlement from the early and high Middle Ages and early medieval graves. The oldest settlement of the Mikov dvor site is represented by the Lengyel culture sherds from the cultural layer. A pit of the Kosihy-Čaka group from the young Eneolithic was studied in the investigated area. Several features dated to the late LaTène period come from the extensive researches at the turn of the $1970 \mathrm{~s}$ and $1980 \mathrm{~s}$. Most studied features, however, belong to the Roman period; one inhumation burial was dated to the final part of this period as well. The rich settlement can be chronologically classified within the Early Middle Ages. The investigated Slavonic settlement together with the cemetery were probably parts of the farming area of the central hillforts from the territory of today's Nitra. Near the investigated 
area, mainly north of it, in the wide space of Mikov dvor, several more or less extensive archaeological investigations were carried out in the past. They detected various features, dwellings and graves from the Middle Ages. Their inventory comprised pot-shaped vessels and items of everyday use. The fill of the settlement features contained fragments of pottery and animal bones. On the northern side of the elevation and in the area reaching the confluence of streams, extensive researches were executed in 1977-1982, resp in 1984. Part of an early medieval settlement from the $6^{\text {th }}-7^{\text {th }}$ century and a habitation from the $9^{\text {th }}-10^{\text {th }}$ century, resp. from the $12^{\text {th }}-13^{\text {th }}$ century, were uncovered. The early medieval settlement is represented by sunken residential features with hearths and stone stoves in the corners, or by storage pits as well as waste pits. 54 inhumation burials can be classified within the period of Great Moravia. Their inventory contained pot-shaped ceramic vessels, knives, spindle whorls, a tinderbox, firestones, an axe, spurs, a needlecase, ring earrings with grape-like hangers and meander-shaped loops, earrings with column-shaped and hollow hangers, a ring, beads and buttons. The last archaeological research at the site of Mikov dvor was carried out in 2017 by PAMARCH, a private company. It revealed settlement from the Neolithic. The area of the archaeological site where graves from the period of the Avar Khaganate were uncovered was intensely used for agricultural purposes. It is located on a terrace-like elevation gradually verging to a slightly undulate ridge which falls to the valley of the Selenec stream in the east. On maps from military surveys (Fig. 2-4), we can notice an undistinct elevation which was used for burying. The investigation started in September 2008, when first disturbed archaeological features were detected in trenches. Since August 2009, an area excavation was carried out. In its first phase (trimming of the area), the Ponitrianske Museum in Nitra participated. Later, the excavations were managed by the Institute of Archaeology of SAS in Nitra. In the final phase of field works (January 2010), 8 inhumation burials were uncovered in the northeastern part of the investigated area. Their plans and material from them are presented in plates (Pl. I-V). With the exception of the southern edge, all boundries of this small necropolis were detected. It follows from the catalogue, that a small group of 8 inhumation burials was studied (Fig. 5). Five of them were intact, two bore distinct traces of secondary interference and as for grave 4, no remains of a human skeleton have been preserved. As far as age and gender of the buried individuals are concerned, children prevail in the group (3 graves), adults were buried in two graves, probably an adult man was buried in grave 6 and also in grave 8 . In the intact graves, the human individuals were deposited stretched on their backs, with upper limbs arranged along their bodies. Various designs of grave pits were mostly used to create a hollow space near the buried body. Remains of grave constructions were observed in three graves at the cemetery in Nitra-Janíkovce. Framework constructions were probably present in graves 1 and 6; narrowings have been preserved above the bottoms. As for grave 5, there was a combination of framework and post construction. In the narrowed space above the bottom, a skeleton of a child was placed. There were posts in all four corners. Four-post constructions are not unusual at cemeteries from the period of the Avar Khaganate. However, they are normally placed in longer walls. Secondary interferences were observed in two cases. Orientation of the graves or axes of grave pits oscillates within the NW - SE to N-S direction $\left(308^{\circ}-354^{\circ}\right)$. Grave 5 is the only exception. The disturbed skeleton was probably originally placed stretched in the $\mathrm{S}-\mathrm{N}$ direction $\left(157^{\circ}\right)$. Meridional orientation of graves is unique during the Avar Khaganate period. To make the data more exact, orientation was also identified by measuring of angles. The inventory from the graves included finds and grave goods. Some of them probably belonged to the dead person. Metal parts of belts, weapons, jewels and luxurious items in general are mainly documents of the buried person's social status. It is a traditional interpretation, however, it is hard to imagine that e. g. a decorated belt with fittings could have been put in a grave of a poor member of a certain society. The second category of grave items are those which probably were not personal possessions of the dead person and are more likely gifts from survivors or are associated with the act of burial (e. g. a vessel, meat offerings in form of animal bones, an egg, etc.). Depositing of grave goods is important from the aspect of their location in the so-called functional position. Belt fittings are usually located near pelvic bones, earrings are found near skulls, necklacess near necks, horse harness on horse skeletons, etc. Grave 6 is the only rich complex at the cemetery in Nitra-Janíkovce. It contained a set of belt fittings deposited on the left pelvic bone or next to it. The garniture consists of a cast strap end (Fig. 6), quadratic sheet metal fittings decorated with rings lined with embossed pearls, a rectangular buckle and a sheet metal adjuster. Large strap ends whose backplates are attached to the strap end body by a hinge are rather unique in the material from the Avar Khaganate, however, they are not an exceptional phenomenon. Most of them are cast bronze exemplars whose ornamentation consists of zoomorphic as well as floral motifs. Several strap ends with hinged backplates were made of gold, silver or gilded silver. They were parts of costumes of prominent Germanic women and they are dated to the early stage of the period in the Avar environment. Wrought rectangular fittings made of sheet metal (Fig. 7) which are typical of the younger phase of the middle stage are extremely important for dating of grave 5 at the cemetery in Nitra-Janíkovce. The considerably massive knife from grave 6 is probably the only item which can be classifed within the group of weapons. Iron buckles, an iron ring, knives, a point, a steel and firestones can be included among the items of everyday use. Five graves from the analyzed cemetery contained ceramic vessels. They are coiled and decorated pot-shaped vessels with combed decoration. Dating of ceramic vessels and items of everyday use in the $8^{\text {th }}$ century is only rough. A bronze coiling from a fibula was found in the backfill of grave 5; the fibula can be with high probability dated to the Roman period. Animal bones come from three graves and in the backfill of two graves, there were remains of molluscan fauna. It was previously assumed that the territory near Nitra was included in the Avar Khaganate during the second half of the $8^{\text {th }}$ century. The set of belt fittings from grave 6 at the cemetery of Nitra-Janíkovce significantly changes this postulate. It can be rather reliably dated to the first quarter or first third of the $8^{\text {th }}$ century. 
A young man was buried in the grave, thus, we can assume the he had owned the set only for a short time. In association with this, we must mention an inhumation burial from Ivanka pri Nitre which contained a vessel of a rather archaic design. An iron stirrup discovered in a settlement feature in Nitra-Chrenová and a trefoil arrowhead found in the fill of feature 232 dated to the early Slavonic period are older than the second half of the $8^{\text {th }}$ century. These data allow the authors to assume that the territory near the town of Nitra was included in the political structure of the Avar Khaganate in the beginning of the $8^{\text {th }}$ century at the latest.

An analyses of anthropological material from grave 6 was carried out in the laboratory in Poznań. Unfortunately, it did not bring the desired exactness in the more specific chronological classification of this assemblage, since the absolute dating has a considerably wide tolerance.

Fig. 1. Nitra-Janíkovce. Cemetery from tha Avar Khaganate period. Location on the map with the scale of 1:10 000 is indicated with the red circle (C GKU).

Fig. 2. Nitra-Janíkovce. Location of the cemetery on the map of the First Military Survey (@ ARCANUM).

Fig. 3. Nitra-Janíkovce. Location of the cemetery on the map of the Second Military Survey (@ ARACANUM).

Fig. 4. Nitra-Janíkovce. Location of the cemetery on the map of the Third Military Survey (C ARACANUM).

Fig. 5. Nitra-Janíkovce. Plan of the cemetery.

Fig. 6. Nitra-Janíkovce. Strap end from grave 6.

Fig. 7. Nitra-Janíkovce. Quadratic sheet metal fittig from grave 6.

Pl. I. Nitra-Janíkovce. Graves 1 and 2.

Pl. II. Nitra-Janíkovce. Graves 3-5.

Pl. III. Nitra-Janíkovce. Grave 6.

Pl. IV. Nitra-Janíkovce. Graves 6 and 7.

Pl. V. Nitra-Janíkovce. Grave 8.

Mgr. Mário Bielich, PhD.

Archeologický ústav SAV

Akademická 2

SK - 94921 Nitra

mario.bielich@savba.sk

doc. PhDr. Matej Ruttkay, CSc.

Archeologický ústav SAV

Akademická 2

SK - 94921 Nitra

matej.ruttkay@savba.sk

doc. PhDr. Jozef Zábojník, CSc.

Archeologický ústav SAV

Akademická 2

SK - 94921 Nitra

jozef.zabojnik@savba.sk 